\title{
Liikettä rajalla
}

TuULIKKI KuRKi: Rajan kirjailijat. Venäjän Karjalan suomenkieliset kirjailijat tilan ja identiteetin kirjoittajina. Suomalaisen Kirjallisuuden Seura, Helsinki 2018. 436 s.

Tuulikki Kurki tarkastelee tutkimuksessaan Rajan kirjailijat suomenkielistä kirjallisuutta Venäjän Karjalassa. Keskeisiä käsitteitä ovat rajaseutu ja sen ei-venäjänkielinen tila. Jälkimmäisen Kurki määrittelee alueelliseksi, ajalliseksi sekä sosiaaliseksi ja kulttuuriseksi olemassaoloksi. Tutkimus käsittelee aikaa toisen maailmansodan päättymisestä 2010-luvun alkuun, ja keskeisenä aineistona on noin sata kaunokirjallista teosta. Näistä tarkempaan analyysiin on valittu seitsemäntoista teosta neljältä kirjailijalta, jotka ovat Nikolai Jaakkola, Antti Timonen, Taisto Huuskonen ja Arvi Perttu. Tarkasteltava kirjallisuus on lajityypiltään kirjoittajien omaa aikaa kuvaavaa proosaa.

Kurki esittelee myös aikaisempaa Venäjän Karjalan suomenkieliseen kirjallisuuteen kohdistunutta tutkimusta, jota ei ole kovin paljon. Tutkimuksissa ko. kirjallisuutta on tarkasteltu toisaalta neuvostoajan poliittista elämää vasten, toisaalta etnokansallisia piirteitä vahvistavana ja ylläpitävänä. Lisäksi kolmesta tunnetusta vienankarjalaisesta kirjailijasta (Ortjo Stepanov, Jaakko Rugojev ja Antti Timonen) on julkaistu elämää ja tuotantoa käsittelevät tutkimukset 2010-luvulla. Tämä tutkimus sijoittuu siis varsin vähän tarkastellulle alueelle ja täydentää siinä mielessä sekä suomenkielistä kirjallisuutta että Venäjän Karjalaa koskevia tutkimuksia uudella näkökulmalla.

\section{Syrjäkylästä neuvostokansalaiseksi ja takaisin}

Tutkimuksen kohteena oleva ajanjakso 1940-luvulta 2010-luvulle on jaettu neljään tarkastelujaksoon, jotka muodostavat myös kirjan pääluvut. Kurki kuvaa jokaisessa luvussa poliittista tilannetta ja sen aiheuttamaa muutosta kirjallisuusinstituutioon ja Karjalan kirjalliseen 
elämään. Tämän jälkeen hän analysoi aineistokirjallisuuden kuvaamaa ei-venäjänkielistä tilaa ja identiteettiä ajalle ominaisten vaateiden ja rajoitusten valossa.

Suomenkielinen kirjallisuus käynnistyi Neuvostoliitossa vallankumoushenkisten lehtien ympärillä 1920-luvulla. Proosakirjallisuutta ja lyriikkaa julkaistiin aluksi pääosin lehdissä ja vasta vähitellen kirjoissa. Neuvostoliiton alkuaikoina ei-venäjänkielisen kirjallisuuden kohdalla noudatettiin ns. juurrutuspolitiikkaa, joka suorastaan suosi etnokansallista kirjallisuutta. Vuonna 1932 perustetun Neuvostokirjailijoiden liiton tavoitteena oli yksi, monikansallinen neuvostokirjallisuus. Eri kieliä ja kansallisuuksia edustavat kirjailijat nähtiin työssä yhteisen ideologian, kulttuurin, neuvostoidentiteetin ja yhteisteisten arvojen rakentamisessa.

Stalinin hallinnon loppuvuosina 1947-1953 kirjallisuudessa kuvattu ei-venäjänkielinen tila rakentui voimakkaimmin suhteessa poliittiseen ja hallinnolliseen keskukseen Moskovaan ja sen edustamaan ideologiaan. Ei-venäjänkielisistä päähenkilöistä kasvoi neuvostokansalaisia, joiden katse kääntyi paikallisesta pimeydestä kohti Moskovaa ja sieltä loistavaa valoa. Etnokansalliset piirteet kirjallisuudessa edustivat vanhaa taantumuksellisuutta, teollistuminen ja erityisesti sähkö symboloivat uutta, parempaa aikaa.

Hruštšovin aika 1954-1966 toi mukanaan kritiikin Stalinin ajan sääntöjä kohtaan. Kirjailijoiden ei ohjeiden nopeasti muuttuessa kuitenkaan aina ollut helppo tietää, minkä verran arvostelua milloinkin sallittiin. Ei-venäjänkielinen tila laajeni, kun etnokansallista paikallisväriä jälleen sallittiin ja suorastaan vaadittiin. Esille nostettiin uudelleen vanha ajatus siitä, että neuvostokirjallisuus muodostuu Neuvostoliiton eri ryhmien kirjallisuudesta. Toisaalta paikallisvärin käyttö myös kaavamaistui, tiettyjä asioita odotettiin. Kerronta liikkui keskusten ja periferian välillä.

Brešnevin ajalla 1967-1982 venäläistämistendenssi jatkui ja voimistui, venäjästä oli tarkoitus tehdä kaikkien toinen äidinkieli. Toisaalta kuitenkin kansallisten kirjallisuuksien vuorovaikutus nähtiin neuvostokirjallisuuden rikastuttajana. Ei-venäjänkielisen tilan kuvaamiseen tuli uusia mahdollisuuksia, kun hyväksytyiksi tekstimuodoiksi nousi kyläproosa, jossa kuvattiin arvostavasti maalais- ja talonpoikaiselämää. Toinen uusi ilmiö oli dokumenttiproosa, jossa dokumentaarinen aines oli punottu yhteen fiktiivisen kerronnan kanssa. Myös maaginen realismi saapui Neuvostoliittoon 1970-luvulla ja oli huipussaan 1980-luvulla. Vaikka liikkumavaraa oli enemmän, oikea aatteellinen suuntautuminen oli tärkeää, ja kaikenlainen Neuvostoliiton mustamaalaamiseksi tulkittava kirjoittaminen tuotti rangaistuksen.

Perestroika merkitsi laajoja rakenteellisia uudistuksia politiikan ja talouden alalla ja oli alkuna uudelle avoimuuden ajalle (glasnost). Monikansallisuus nousi tärkeäksi kysymykseksi, kansallisuuskysymyksiä koskeva sensuuri löyhtyi ja kielipoliittiset liikkeet voimistuivat. Karjalan ongelmana oli suomenkielisten kirjailijoiden väheneminen 1990-luvulla, kun vanha sukupolvi poistui kirjallisuuselämästä. Kun Neuvostoliiton hajotessa sosialistinen realismi menetti asemansa virallisena metodina, kirjallisuuden henkilöhahmot murtautuivat ulos ideaaleista. Päähenkilö saattoi olla identiteetiltään postmodernin pirstoutunut ja liikkuva, myös suoranainen antisankari, ja traumaattiset kokemukset ja vaietut kysymykset pääsivät esille. Toisaalta kirjallisuus oli hämmennyksen tilassa, kun ideologisten vaatimusten poistuessa ei tullut mitään tilalle, ja kirjalliset instituutiot olivat kaaoksessa. Markkinatalouteen siirtyminen vaikutti julkaisumahdollisuuksiin ja myös kirjailijoiden toimeentuloon.

Olen tässä arviossa tiivistänyt ja nostanut valikoiden esille joitakin yleisiä asioita, joita Kurki on tarkastellut huolellisessa analyysissaan. Kurki käsittelee em. kausia laajasti ja monipuolisesti sekä kaunokirjallisuusaineistojen että muiden aineistojensa avulla. 


\section{Kysymys kielestä}

Kieli on eräs keskeinen identiteetin osa-alue. Neuvosto-Karjalan kirjailijat ovat kirjoittaneet suomeksi, vaikka se ei ole ollut heidän kaikkien äidinkieli. Kurki kuljettaa kielikysymystä mukana koko tutkimuksessa, mutta aihetta olisi mielestäni voinut pohtia vielä enemmänkin.

Neuvostoliiton alkuaikoina ei-venäjänkielisiä ryhmiä kannustettiin käyttämään etnokansallisia kieliä venäjän rinnalla. Myös hallinnollisten virkojen täytössä edellytettiin paikallisen kielen osaamista. Tarkoituksena oli sitoa eri etnokansalliset ryhmät käytännöllisin ja symbolisin sitein rakentuvaan neuvostovaltioon. Neuvosto-Karjalan etnokansallisia ryhmiä olivat karjalaiset, inkerinsuomalaiset, vepsäläiset ja suomalaiset.

Neuvosto-Karjalan paikalliseksi etnokansalliseksi kieleksi määriteltiin suomi, vaikka Neuvostoliiton perustamisvaiheissa suomen kieltä puhuvia oli vain yksi prosentti Neuvosto-Karjalan väestöstä. Kurki toteaa yhtenä syynä olleen Neuvosto-Karjalan paikallishallinnon suomalaispainotteisuuden. Poliittiset emigrantit toimivat aktiivisesti myös Neuvosto-Karjalan kirjallisuus- ja kulttuurielämässä. Alueella vaikutti 1920- ja 1930-luvuilla noin neljäkymmentä Suomesta emigroitunutta kirjailijaa, joista osalla oli ollut vakiintunut asema kirjailijoina jo Suomessa. Toinen syy oli, että koska karjalan murteet poikkesivat suuresti toisistaan, yhden karjalan kielen luominen olisi ollut hyvin hankalaa. Suomen kieli oli vakiintunut kieli, jolla oli jo olemassa kirjallisuutta, ja erityisesti vienankarjalaiset ymmärsivät suomea varsin hyvin.

Suomen kielestä tuli pakollinen oppiaine kouluissa, ja vuoteen 1932 mennessä opetus oli muutettu suomenkieliseksi. Suomea käytettiin opetuskielenä ainakin jonkin verran myös ammatillisissa oppilaitoksissa ja yliopistossa. Karjalan kielestä ei kehitetty standardoitua kieltä, vaan se pysyi puhekielenä. Suomen kieli oli virallisessa asemassa venäjän rinnalla vuodesta 1923 vuoteen 1937.

Vuonna 1934 Stalin lopetti etnokansallisia ryhmiä suosineen juurrutuspolitiikan. Pyrittiin myös etnokansallisten kielten latinalaispohjaisten kirjoitusjärjestelmien muuttamiseen kyrillisiksi. Vuonna 1937 suomen kielen käyttö kiellettiin ja seuraavana vuonna venäjän kieli tuli kouluissa pakolliseksi aineeksi. Kun suomen kieli oli taantumuksellisena kielletty 1937-1939, karjalan kieli sai hetkeksi virallisen aseman. Tavoitteeksi asetettiin yhden karjalan kirjakielen luominen. Tämä onnistui heikosti: kyrillisin kirjaimin kirjoitettu karjala oli suullisten karjalan murteiden, venäjän ja suomen sekoitus.

Talvisodan jälkeen suomen kieli otettiin taas käyttöön Neuvosto-Karjalassa. Yhtenä syynä tähän oli, että Neuvostoliitto suunnitteli Suomen miehittämistä, joten kielellä olisi tulevaisuudessa käyttöä. Suomen kielen virallisen aseman palauttaminen merkitsi karjalan yhteisen kirjakielen kehittämisen loppumista. Vaikka suomi menetti virallisen asemansa vuonna 1956, se säilyi kuitenkin Neuvosto-Karjalan hallinnon ja kulttuurin kielenä, koska karjalaa ei ollut kehitetty kirjoitetuksi kieleksi. Suomen kielen taito ei kuitenkaan kaikilla riittänyt kirjallisuuden lukemiseen, saati kirjoittamiseen. Venäjän kielen valta-asema aiheutti suomen ja karjalan käytön vähenemisen puhekielenäkin, kun vanhemmat näkivät venäjän kielen tienä lastensa menestykseen.

Kielikysymyksessä on siis ollut vallalla kaksi hyvin erilaista mielipidettä: toisaalla on pidetty järkevänä käyttää kirjakielenä suomea, joka on kirjoitettuna kielenä jo vakiintunut, joskus haluttiin jopa kehittää puhuttua karjalaa kirjasuomen suuntaan. Toisaalla taas on painotettu karjalan kielen asemaa omana kielenä ja sen kehittämisen ja tutkimuksen tarpeellisuutta. 


\section{Maailman rajoilla}

Tuulikki Kurjen tutkimuksen kohteena on Neuvosto-Karjalan ja Venäjän Karjalan suomenkielisen kirjallisuuden kuvaama ei-venäjänkielinen tila ja identiteetti. Tutkimuksen keskeisinä kiintopisteinä toimivat Venäjän Moskova-johtoinen kirjallisuusinstituutio, Neuvostoliiton/ Venäjän ja Suomen valtiolliset ja symboliset rajat sekä Neuvostoliiton hajoamisen synnyttämä katkos alueen suomenkielisen kirjallisuuden kentässä. Kirjallisuuden yksittäistapausten välityksellä tutkijalla on pääsy yleismaailmallisiin identiteetin kokemuksiin. Kurki sijoittaakin Venäjän Karjalan suomenkielisen kirjallisuuden maailman rajakirjallisuuden keskiöön, sillä sen kuvaamat identiteetit ja tilat heijastavat samoja kokemuksia, joita rajaseutujen ihmisillä on ympäri maailmaa.

Kurki tarkastelee analyysissaan rajaseutua liikkeessä olevana tilana, joka toimii identiteettien rakentamisen perustana. Suomenkielistä kirjallisuutta rakennettiin osana neuvostokirjallisuutta 1920-luvulta lähtien. Neuvostoaikana kirjallisuudessa tavoiteltiin yksiäänisyyttä, ideologista ja alueellistakin yhtenäisyyttä. Perestroikan aikaan ja Neuvostoliiton hajoamisen jälkeen Venäjän Karjalan suomenkielisessä kirjallisuudessa nousi esiin uusia narratiiveja, kuten selviytymisen, siirtymisen ja liikkeessä olemisen narratiivit.

Kiinnostava sivujuonne on myös kysymys kielestä. Kun Neuvosto-Karjalan omaksi kieleksi valittiin suomi, se merkitsi omanlaisensa ulkosuomalaisen suomenkielisen kirjallisuuden syntymistä. Samalla se teki melko tarpeettomaksi karjalan kirjoittamisen ja karjalan kirjakielen kehittämisen. Suomeksi kirjoittaminen oli yksi Neuvosto-Karjalan ei-venäjänkielistä tilaa ja identiteettiä rajaava tekijä. Kurki ei nosta kielikysymystä erikseen esille, vaan kuljettaa sitä tulkinnoissa mukana pitkin matkaa.

Rajan kirjailijat on kiinnostava ja monin tavoin silmiä avaava lukukokemus. Runsas yksityiskohtien määrä tekee kirjasta paikoin raskaslukuisen, mutta samalla vakuuttaa lukijan. Kirjan rikkaaseen sisältöön voi palata myöhemminkin, tässä on apuna kirjan lopun teos- ja asiahakemisto.

MERJA LEPPÄLAHTI

meleppa@utu.fi

Folkloristiikka

20014 Turun yliopisto 